\title{
Serum levels of inflammatory cytokines in leprosy patients
}

\author{
Lúcia de Paula ${ }^{1 *}$, Isabella Motta Passos ${ }^{1}$, Rossilene Conceição da Silva ${ }^{1}$, Adriana Malheiro², \\ George Allan Villarouco Silva', Maísa Porto dos Santos', Maria da Graça Souza Cunha ${ }^{1}$ \\ From $16^{\text {th }}$ International Symposium on HIV and Emerging Infectious Diseases \\ Marseille, France. 24-26 March 2010
}

\section{Background}

Measure the serum cytokine levels in untreated leprosy with different parts of the spectrum of leprosy.

\section{Methods}

Concentrations of IL-4, IL-6 and IL-12 in the serum of patients were determined with a commercially available enzyme-linked immunosorbent assay (ELISA) kit (R\&D Systems) according mannufactors instructions.

\section{Results}

We observed that mean of IL-4 and IL- 6 were higher in lepromatous pole and IL-12 and TNF- $\alpha$ were higher in tuberculoid pole, but only IL-12 were statistic significantly. Our data also demonstrated that most of the patients present very lows or absent levels of TNF- $\alpha$, IL- 4 and IL- 6 .

\section{Discussion}

This is probably because leprosy is a chronic infectious disease and this profile cytokines is increase acute infections. Thus, studies of cytokine in leprosy have given us a more detailed description of the immunological parameters of the polar types of leprosy and play a significant role in classification and prognosis of this disease.

\section{Author details}

${ }^{1}$ Fundação Alfredo da Matta, Manaus, AM, Brazil. ${ }^{2}$ Fundação de Hematologia e Hemoterapia do Amazonas, Manaus, AM, Brazil.

Published: 11 May 2010

doi:10.1186/1742-4690-7-S1-P190

Cite this article as: de Paula et al:: Serum levels of inflammatory cytokines in leprosy patients. Retrovirology 2010 7(Suppl 1):P190.

* Correspondence: Ipaula@fuam.am.gov.br

'Fundação Alfredo da Matta, Manaus, AM, Brazil
Submit your next manuscript to BioMed Central and take full advantage of:

- Convenient online submission

- Thorough peer review

- No space constraints or color figure charges

- Immediate publication on acceptance

- Inclusion in PubMed, CAS, Scopus and Google Scholar

- Research which is freely available for redistribution

Submit your manuscript at www.biomedcentral.com/submit
C Biomed Central 